\title{
Modelling the Movement of some Mobile Hydrocarbons Below the Crop Rooting System Using Small-Scale Lysimeters with Undisturbed Soils
}

\author{
ANCA-ROVENA LACATUSU', HORIA DOMNARIU ${ }^{1}$, DORA MARICA ${ }^{1}$, \\ CRISTIAN PALTINEANU ${ }^{1 *}$, ANDREI VRINCEANU ${ }^{1}$, ANDREIA VLADIMIRESCU ${ }^{2}$ \\ ${ }^{1}$ National Research and Development Institute for Soil Science, Agrochemistry and Environment - ICPA Bucharest, \\ 61 Marasti Blvd., 011464, Bucharest, Romania \\ ${ }^{2}$ ICPT Campina OMV Petrom SA, 29 Culturii Blvd., 105600, Câmpina, Romania
}

\begin{abstract}
The presence of hydrocarbons in groundwater represents a serious risk of disease. This study tests the timing, concentration and amount of BTEX oil components during the oil vertical movement though small-scale lysimeters containing undisturbed soils of different textures and by simulating the fate of oil spills under continuous water application. Three soil types were studied: a sandy-textured, highly permeable Eutric Arenosol, AR-eu, a loamy/sandy-loamy textured Haplic Chernozem, CH-ha, and a loamy-clayey/clayey textured, swell-shrink, Luvic-Chernic Phaeozem, PH-ch-lv. Crude oil was applied as a batch application using an equivalent of $5 \mathrm{~g}$ oil $/ 100 \mathrm{~g}$ of dry soil for a $0.02 \mathrm{~m}$ height in each lysimeter of the three soils studied. After oil-penetration into the soil, tap water was applied on a daily basis above the lysimeters according to infiltration rate. The breakthrough curves of the BTEX compounds show that the highest mobility in the investigated sandy AR-eu soils and loamy CH-ha soils was found for benzene followed by toluene. The other hydrocarbons only showed a limited mobility. There was no leachate from the swell-shrink PH-ch-lv soil. Soil texture and permeability thus play an important role in the movement of BTEX compounds toward the groundwater. After applying an amount of water of $200 \%$ from the total soil porosity, or an equivalent of $800-850 \mathrm{~mm}$ of precipitation, the leaching process did not end and there still is a leaching potential remained for these hydrocarbons. The highest amount leached per mm of effluent was also for benzene followed by toluene. There were highly significant, direct correlations between the amounts of the hydrocarbons leached and the cumulative effluent volume. The swell-shrink soils are still an effective barrier to hydrocarbons movement toward groundwater. The BTEX aromatic hydrocarbons leached from the soils, if reach the groundwater, represent sources of pollution with severe risks for human health.
\end{abstract}

Keywords: BTEX, benzene, toluene, ethylbenzene, m-p-o-xylene, soil permeability, soil texture

\section{Introduction}

Oil spills can occur everywhere on earth, not only in regions with important petroleum industry, but also across oil-transportation system lands. For instance, a significant deterioration of the Niger River water quality was reported due to oil spills in its Delta with regard to turbidity, conductivity, heavy metals, phytoplankton, zooplankton and microbial diversities [1]. Severe polluted areas with benzene were found in some regions of India [2], while more recently oil movement into sandy soils situated on coastal areas in Qatar to control environmental pollution was studied [3]. The presence of hydrocarbons in groundwater represents a serious risk of diseases, even cancer, specifically among children [4-8]. According to [8], exposure to toluene may cause serious neurological and cardiovascular problems, as well as various adverse effects in kidney and liver, while ethylbenzene may affect the neurological system and exposure to xylenes may cause hepatic, neurological, and renal diseases.

Flow of water and fluids into the soil is a complex process. Water flow is highly important, not only for soil formation conditions in the nature but also for leaching of nutrients and soluble or insoluble pollutants through miscible displacement toward groundwater [9].

\footnotetext{
*email: cristian.paltineanu@icpa.ro
} 
Studying soil water flow has been performed under both field- and laboratory-conditions, and this represents the experimental base for many simulation models.

Water infiltration and leaching of fertilizers and various chemicals into the soil have been investigated in either large, hydrologically-isolated plots endowed with drainage systems and other technical facilities [10] or small-scale plots of a few square meters [11], as well as at river catchment scale [12]. Lysimeters and soil columns have also been used to study movement of many chemical solutions [13-15].

Oil movement into the soil has been studied as a result of oil spills at soil surface mainly related to oil exploitation. Thus, specific hydrocarbons features on soil physical and chemical properties when moving laterally or vertically inside the soil were reported by [16]. Hydrocarbons also possess hydrophobic properties and can be stored in the soil. Their soil distribution dependents, among other characteristics, on soil porosity, pore air pressure, water, and hydrocarbons themselves [16]. Soil permeability for hydrocarbons is different from the soil permeability for water, due to differences in viscosity. Some mobile hydrocarbon components show different velocities through the soil, i.e. chromatographic separation [16].

In Romania, observations have been made by inhabitants of villages across oil-industry operated areas that water table was polluted with oil after rainy years some decades ago. Some scientists [17-18] reported oil-polluted areas across the country, occurring particularly in its south-eastern part, and discussed changes in some soil chemical properties down to 1-m depth for some loamy-textured chernozems affected by hydrocarbon pollution. More recently, some researchers [19-21] studied decontamination of a soil artificially polluted with crude oil concerning the removal of total petroleum hydrocarbons during various time-scale scenarios with regard to bioremediation. In the same context, correlations were found between the dynamics of efficiency on total petroleum hydrocarbons concentration and bioremediation process in soils polluted with crude oil [18].

Because experiments on large field plots using oil movement into the soil are not possible due to its severe risk of environmental pollution, such themes have either been studied in already polluted areas, or in lysimeters or soil columns. Lysimeters are generally devices used to measure evapotranspiration and/or soil water drainage, being of either weighing or non-weighing type. Lysimeters and soil columns have a serious disadvantage in research because the environmental conditions are simplified; they have, however, the advantage of a permanent control regarding the application of a continuous percolation treatment and effluent collection. The factors controlling the experiment can thus be properly analyzed and highlighted.

Studies on movement of pollutants have been mostly carried out in small soil columns containing disturbed soils. The experimental conditions of such studies do not properly meet the requirements of a minimum representative soil volume, nor do they meet the requirements of natural conductive soil properties considering larger pores or cracks. Additionally, oil movement in various-textured soils has not been sufficiently investigated either, existing thus a knowledge gap in this field.

The purpose of the present study is to test the timing, concentration and amount of some mobile aromatic hydrocarbons, namely BTEX oil components (mixtures of benzene, toluene, ethylbenzene, meta-xylene and para-xylene combined and ortho-xylene) during the oil vertical movement though small-scale lysimeters containing undisturbed soils of different textures and by simulating the fate of oil spills under continuous water application.

\section{Materials and methods}

\subsection{Natural conditions of the studied site}

The southern part of Romania, where this investigation has been carried out, has a temperatecontinental climate with mean annual air temperatures generally ranging from 10.5 to $11.0^{\circ} \mathrm{C}$, with an increasing trend for itself and for reference evapotranspiration and crop evapotranspiration alike [2225]. Mean annual precipitation in the region varies between 500 and $600 \mathrm{~mm}$, with most of the rainfall, i.e. 320-400 $\mathrm{mm}$, occurring during the growing season, and the rest, 180-200 $\mathrm{mm}$, during the cold and 
wet season (from October up to March); actually, the precipitations are not distributed homogeneously during the year, and there are cycles of rainy years and droughty years, as well, when there is a need of irrigation application [26, 27].

Soils in Romania show a great diversity, as well as the relief, geology and climate do. From the point of view of soil texture, there is a large range from sandy to loamy and clayey soils in the study region and in the country alike (ICPA Bucharest Archive); there is similar soil texture diversity at global scale [28].

The material of this study is represented by three different textured soil types: a) a sandy-textured, highly permeable Eutric Psamosol [29], or Eutric Arenosol, symbol AR-eu [30] with the geographical coordinates of $43.779^{\circ} \mathrm{N}, 24.2078^{\circ} \mathrm{E}$ and $61 \mathrm{~m}$ above sea level (a.s.l.), in Potelu-Ianca village, Olt county, b) a loamy/sandy-loamy textured Cambic Chernozem, or Haplic Chernozem, symbol CH-ha, having the coordinates of $44.790^{\circ} \mathrm{N}$ and $26.939^{\circ} \mathrm{E}, 62 \mathrm{~m}$ a.s.l., in Grindu village, Ialomita county, and c) a loamyclayey/clayey textured, swell-shrink, Chernic-Argic Phaeozem, or Luvic-Chernic Phaeozem, PH-ch-lv, with $44.09337^{\circ} \mathrm{N}, 25.54698^{\circ} \mathrm{E}$ geographical coordinates, and $89 \mathrm{~m}$ a.s.l., in Draganesti village, Teleorman county.

Soil profiles were dug up in the selected areas to characterize pedogenetic horizons and to take from each horizon both disturbed and undisturbed samples that were analyzed in the laboratory of National Research and Development Institute for Soil Science, Agrochemistry and Environment - ICPA Bucharest, according to the current standardized methods [31]: particle-size distribution, bulk density (BD), saturated hydraulic conductivity $(\mathrm{Ks}), p \mathrm{H}$, organic carbon content, NPK, and other current physical and chemical analyses.

The most important part of the soils is generally represented by the plant rooting depth that approximates about $1 \mathrm{~m} \mathrm{[32],} \mathrm{and} \mathrm{it} \mathrm{is} \mathrm{this} \mathrm{part} \mathrm{of} \mathrm{the} \mathrm{vadose} \mathrm{zone} \mathrm{that} \mathrm{is} \mathrm{mostly} \mathrm{affected} \mathrm{by} \mathrm{pollution}$ with pesticides, heavy metals, excess fertilizers and other inorganic or organic chemical products. The transport of pollutants toward groundwater depends on many soil properties, primarily on texture and bulk density, which determines the conductive soil properties [33-35].

For the three soil types studied, the 1-m depth weighted-mean for clay $(<0.002 \mathrm{~mm})$ content was $0.51 \% \mathrm{~kg} \mathrm{~kg}^{-1}$ for AR-eu, $20.2 \% \mathrm{~kg} \mathrm{~kg}^{-1}$ in the case of CH-ha, and $47.4 \% \mathrm{~kg} \mathrm{~kg}^{-1}$ for PH-ch-lv, while Ks showed the following weighted-harmonic means over $1 \mathrm{~m}$ depth: $201.5 \mathrm{~mm} \mathrm{~h}^{-1}$ for AR-eu, $17.04 \mathrm{~mm}$ $\mathrm{h}^{-1}$ in $\mathrm{CH}-\mathrm{ha}$, and $2.44 \mathrm{~mm} \mathrm{~h}^{-1}$ in PH-ch-lv. The soil $\mathrm{pH}$ varied between 6.2 and 7.0 for AR-eu soil type, and between 5.0-5.6 in the topsoil and 7.0-8.4 in the subsoil of $\mathrm{CH}$-ha and PH-ch-lv soil types. The soil organic carbon content, as well as the NPK soil content decreased from topsoil to subsoil in all the three soil types studied. More data on the soil physical and chemical properties can be read in a previous paper [36].

\subsection{Soil sampling in small-scale lysimeters}

Water was applied over the studied soils in the field for about six hours according to the infiltration rate in order to bring the soils to field capacity and remove the entrapped air from the soil pores. A few days later, metal small-scale lysimeters made by stainless steel, $0.3 \mathrm{~m}$ in diameter and $1 \mathrm{~m}$ in length, were inserted into the soil by hitting repeatedly with a sledge hammer over a round and thick metal lid laid over the lysimeters' edge until they penetrated about 0.05 to $0.10 \mathrm{~m}$ into the soil. Afterwards, the soil outside the lysimeters was removed, and these steps were followed continuously until the entire devices were inserted into the soil. After the soil was cut horizontally at the lysimeters bottom, the fullof-soil lysimeters were tied up at both sides and then were transported to the lab in order to be investigated. At least three lysimeters were used for sampling each soil type: AR-eu, PH-ch-lv, and CHha. Each lysimeter was placed above a stainless steel stand provided with a $0.05 \mathrm{~m}$ high two-layered drainage system that continued with a sieve over a tap-outlet device designed for effluent collection.

\subsection{Conditioning the soil lysimeters for oil and water application}

Crude oil was applied as a batch application using an equivalent of $5 \mathrm{~g}$ oil /100 g of dry soil, an amount 
also used by other scientists [37] for a $0.02 \mathrm{~m}$ lysimeter height, i.e. $0.92 \mathrm{~kg}$ of oil in each lysimeter of the three soils studied, in three replicates. The oil has had the following properties: $0.074 \mathrm{~kg} \mathrm{~kg}^{-1}$ total sulphur, $0.8292 \mathrm{~kg} \mathrm{dm}^{-3}$ density at a temperature of $20^{\circ} \mathrm{C}, 5.33 \times 10^{-6} \mathrm{~m}^{2} \mathrm{~s}^{-1}$ kinematic viscosity, and $-12^{\circ} \mathrm{C}$ freezing point.

The BTEX components studied were benzene $\left(\mathrm{C}_{6} \mathrm{H}_{6}\right.$, with the highest water solubility and volatility from all), toluene $\left(\mathrm{C}_{7} \mathrm{H}_{8}\right.$ hardly soluble in water), ethylbenzene $\left(\mathrm{C}_{6} \mathrm{H}_{5} \mathrm{CH}_{2} \mathrm{CH}_{3}\right.$, with lower water solubility), meta-xylene $\left(\mathrm{C}_{8} \mathrm{H}_{10}\right.$, somehow water-soluble at higher temperature and various pressure values) and para-xylene combined, as well as ortho-xylene. Generally, the BTEX components, represent an important part of petroleum hydrocarbons through their mobile behavior, even if their fractions from crude oils is not high (varying between about 0.3 and $1.8 \%$ from total hydrocarbons content in various crude oils from different places in the world [7], with benzene up to $0.3 \%$, toluene up to $0.6 \%$, ethylbenzene up to $0.4 \%$, meta- and para-xylene up to $0.6 \%$ and ortho-xylene with $0.2 \%$.

The BTEX components represent the following percentage values by mass of crude oil [38]: benzene 0.17 to 0.30 , toluene 0.74 to $0.81 \%$, ethylbenzene 0.22 to 0.24 , and xylenes 0.86 to $0.94 \%$, respectively. These values are very close to each other regardless the source.

Estimating the BTEX amounts applied to the soil using literature data [7], the following quantities were administered: $2.8 \mathrm{~g}$ of benzene, $5.52 \mathrm{~g}$ of toluene, $3.68 \mathrm{~g}$ of ethylbenzene, $5.52 \mathrm{~g}$ of $\mathrm{m}$ - and $\mathrm{p}$-xylene and $1.84 \mathrm{~g}$ of o-xylene, and $19.3 \mathrm{~g}$ of total BTEX. Other scientists [5,39] also reported BTEX contents that are similar (2-2.2\% of total crude oil) to those reported by literature [7].

The soil from the $0.2 \mathrm{~m}$ lysimeter depth and the oil amount to be applied were mixed and homogenized outside of the lysimeters, and this mixture was then put back in the lysimeters, thus simulating moderate oil pollution over the soil, followed by typical agricultural oil incorporation into the soil by plowing and disking.

After the complete oil-penetration into the soil, tap water was applied on a daily basis above the lysimeters according to the soil infiltration rate for three to four months, thus simulating a continuous period of rainfall and downward soil water flux. This time period is consistent with the findings earlier reported by literature $[19,21]$, according to which the highest bioremediation period was between 3 and 5 months. The effluent amount was different in the studied lysimeters and was collected in dark glass bottles for analyses of oil-derived components. The effluent samples were preserved using a solution of $2 \mathrm{~mL} \mathrm{H}_{2} \mathrm{SO}_{4} / \mathrm{L}$ water to decrease the $p \mathrm{H}$ below 2, then they were covered with aluminum foil, kept in darkness and refrigerated until analyzed. The BTEX components in water were determined with the standardized methods for volatile organic compounds in aqueous samples [40]. The equipment is composed of two major blocks: a Hewlett Packard 5890 Series II Gas Chromatograph (GC) with a Hewlett Packard 5972 mass spectrometer detector (MSD) and a Hewlett Packard 7695 Purge \& Trap concentrator to introduce water samples.

Within the laboratory experiment we simulated a wet and cold season. The laboratory air temperature has been ranging from 8 to $12^{\circ} \mathrm{C}$.

The experimental data were processed using Microsoft Excel. Student t-test was used for testing the significance differences between arithmetic means, regression lines, and coefficients of correlation.

Because at the start of experiment the soils were wet at field capacity, the amount of water applied during the entire period was practically equal to the effluent volume collected below the soil lysimeters. This effluent amount generally represents an equivalent of precipitation between 700 and $860 \mathrm{~mm}$, i.e. $125-155 \%$ from the annual precipitation for the $\mathrm{CH}$-ha area, and 150-170\% for the AR-eu area, respectively. The above effluent values (in $\mathrm{mm}$ ) correspond to a total soil porosity of 160 to $210 \%$. The transformation relationship is derived from [34]:

$$
\mathrm{Ve}=\mathrm{TP} \times \mathrm{Ve} / \mathrm{S}
$$

where: Ve - volume of the effluent $(\mathrm{mm})$; TP - total soil porosity $\left(\mathrm{dm}^{3}\right) ; \mathrm{S}$ - lysimeter cross-sectional area $\left(\mathrm{dm}^{2}\right)$. 


\section{Results and discussions}

\subsection{Results}

\subsubsection{Concentration of the aromatic hydrocarbons as a function of effluent volume}

Figure 1a-1e presents the breakthrough curves of the following aromatic hydrocarbons: benzene, toluene, ethyl-benzene, meta-xylene and para-xylene combined, and ortho-xylene, i.e. mean values and correspondent standard deviations $( \pm \mathrm{SD})$, depending on the effluent collected below each lysimeter, for both AR-eu and CH-ha soil types.

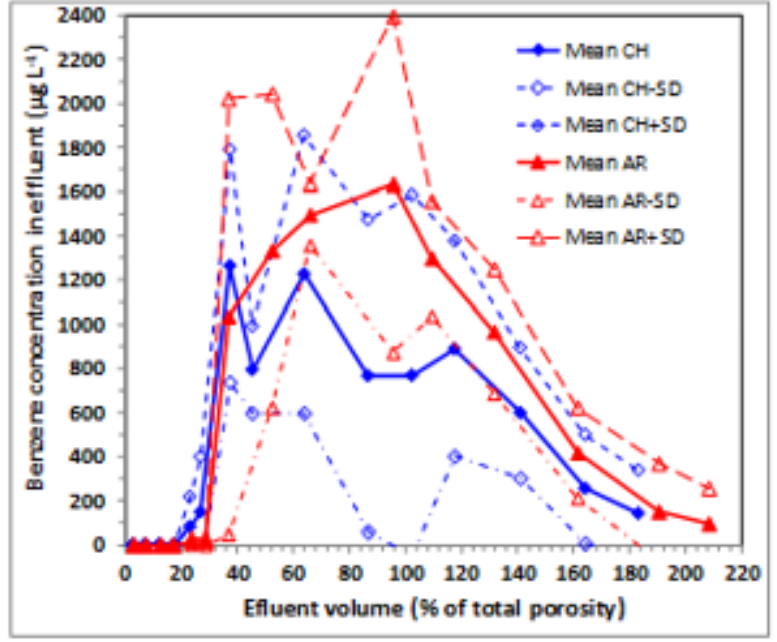

a)

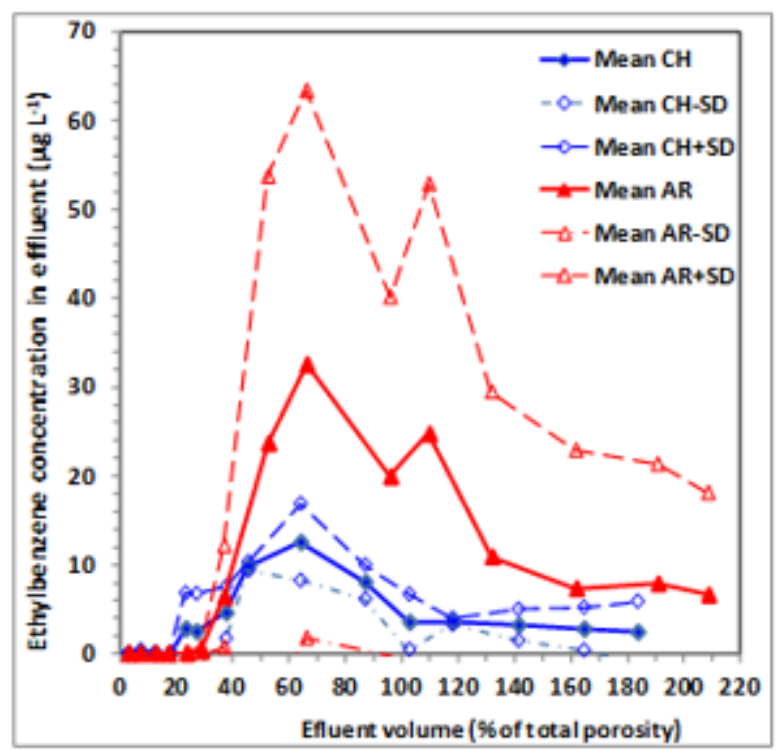

c)

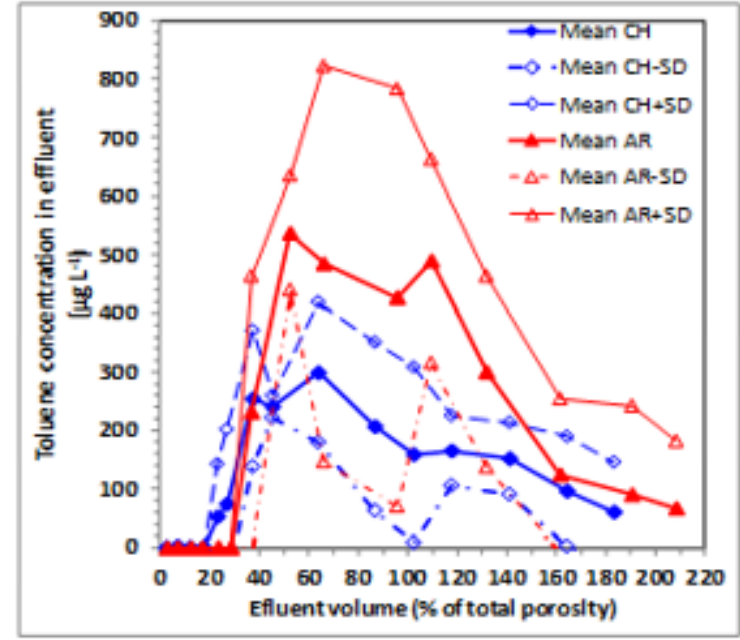

b)

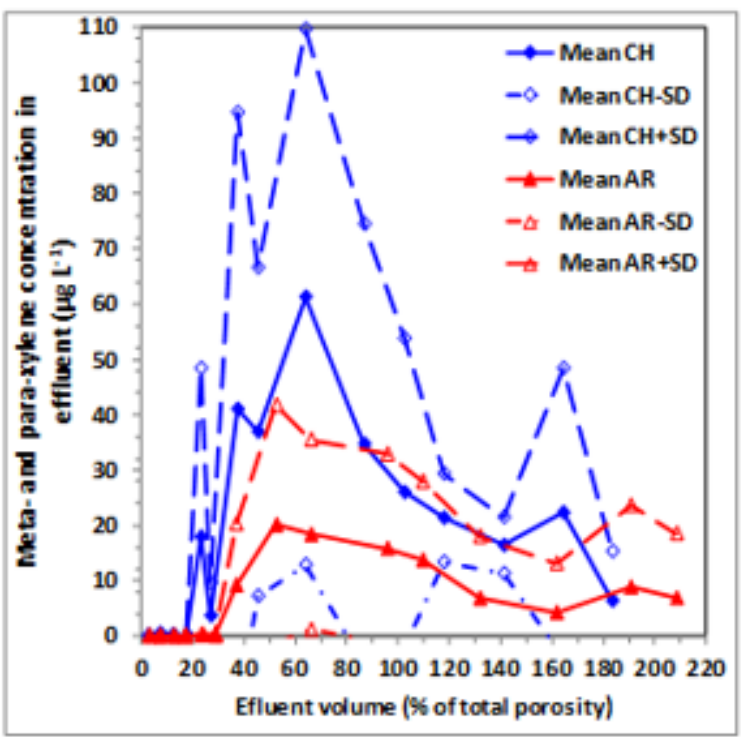

d) 


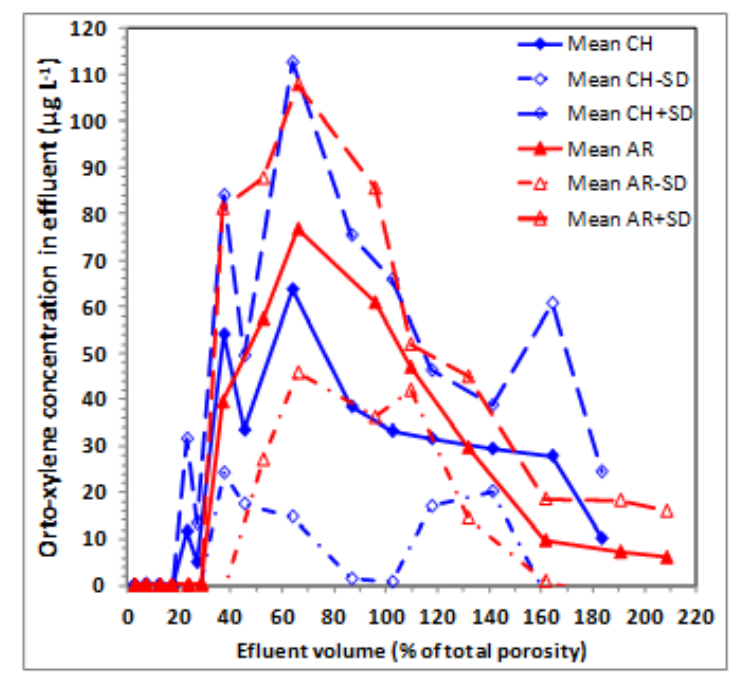

e)
Figure 1. Concentration of the studied mobile aromatic hydrocarbons a function of effluent volume collected below the soil lysimeters for both AR-eu and $\mathrm{CH}$-ha soil types (means $\pm \mathrm{SD}$ )

There was no leachate from the swell-shrink PH-ch-lv soil type. The highest mean values are reported for benzene, i.e. $1634 \mu \mathrm{g} / \mathrm{L}$ after a leached effluent value of about $95 \%$ of total porosity (or $395 \mathrm{~mm}$ of equivalent precipitation) in the case of the sandy soil (AR-eu), and 1250-1270 $\mu \mathrm{g} / \mathrm{L}$ after about 37-60\% $(150-270 \mathrm{~mm})$ of effluent in the case of the loamy $\mathrm{CH}$-ha soil. The other aromatic hydrocarbons showed substantially lower peak values: about $550 \mu \mathrm{g} / \mathrm{L}$ for toluene in AR-eu and about $300 \mu \mathrm{g} / \mathrm{L}$ in CH-ha. The highest values for ethyl-benzene, meta-xylene and para-xylene combined, and ortho-xylene did not exceed $110 \mu \mathrm{g} / \mathrm{L}$.

A common characteristic of all these hydrocarbons is that there was a slight increase in their concentration starting from the first $25-35 \%$ of the leached effluent until it reached the lysimeters bottom; then a sharp increase occurred until their peaks that essentially happened in the first half of the effluent range in the graphs; the descending part of the curves occurred somewhat asymmetrically, but the leaching process did not cease at the end of experiment and the leaching potential still remained important for these hydrocarbons.

Flowing out of the 1-m soil depth, the leaching would probably have occurred deeper into the subsoil and into the geological deposits underneath, toward groundwater.

\subsubsection{Amount of the aromatic hydrocarbons leached per $\mathrm{mm}$ of effluent beyond the 1-m soil depth}

Figure 2a-2e shows the amount of the aromatic hydrocarbons leached beyond the 1-m soil depth per $\mathrm{mm}$ of effluent in each soil lysimeter, for both AR-eu and $\mathrm{CH}$-ha soil types.

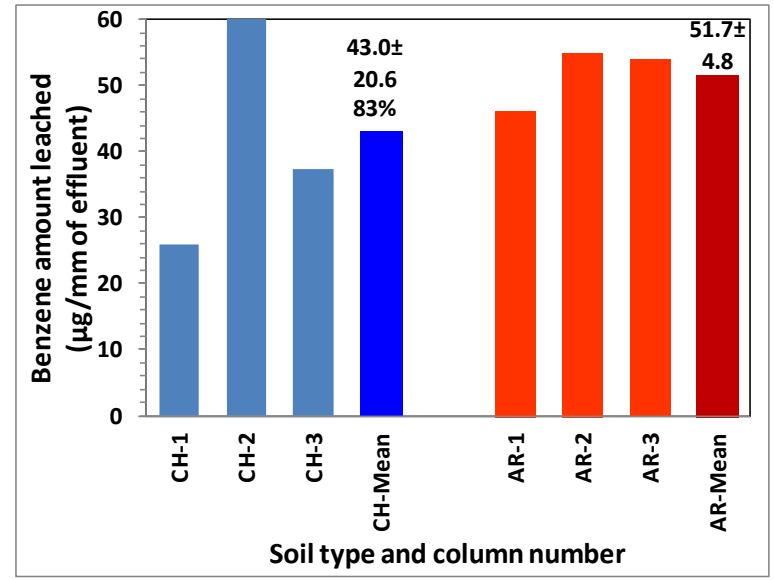

a)

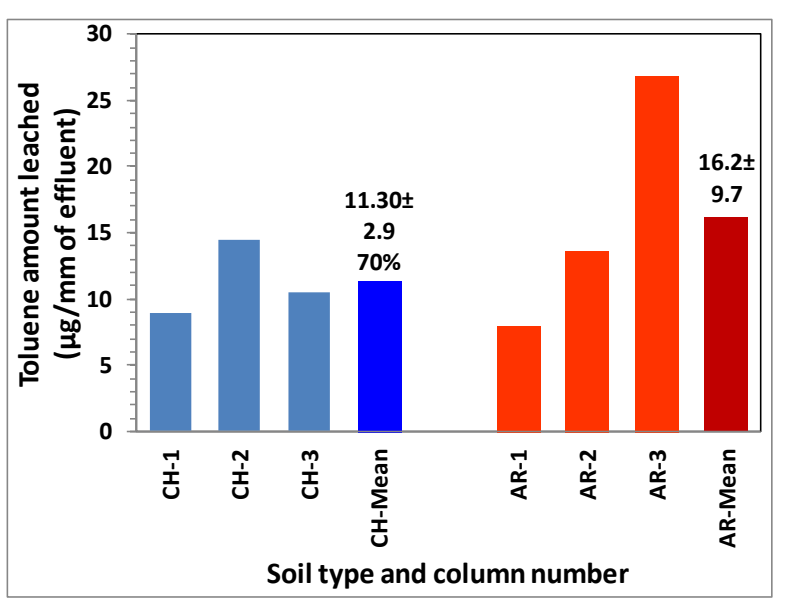

b) 


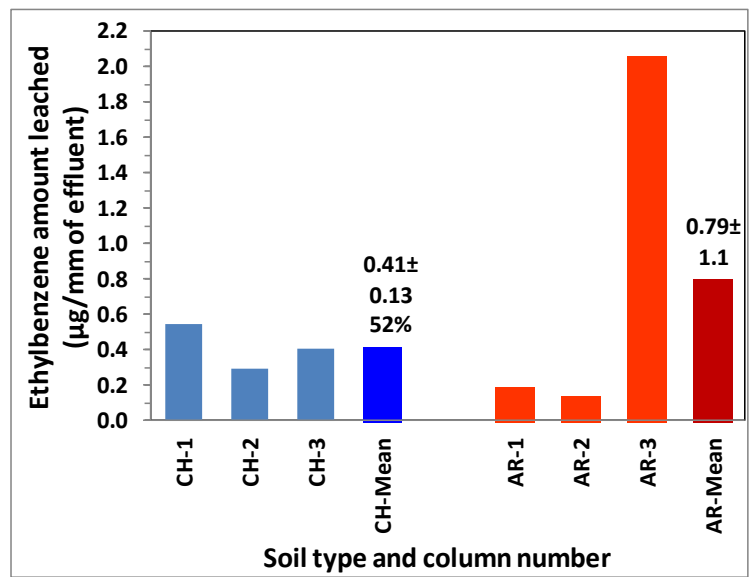

c)

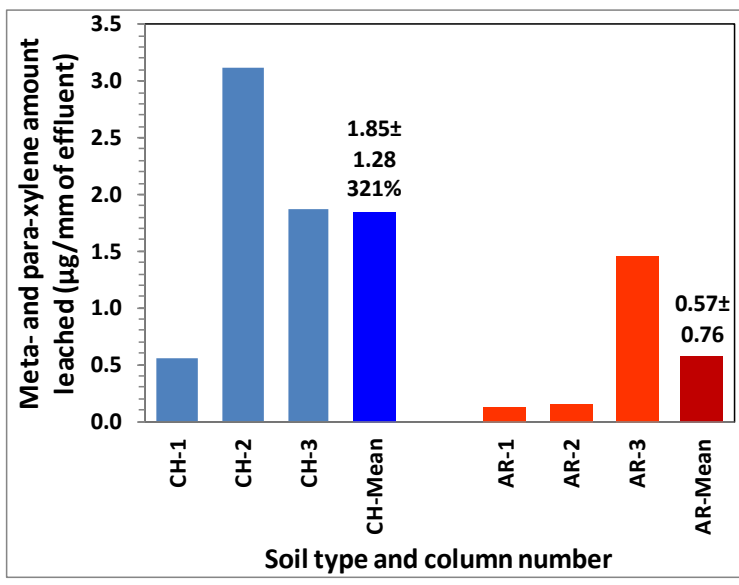

d)

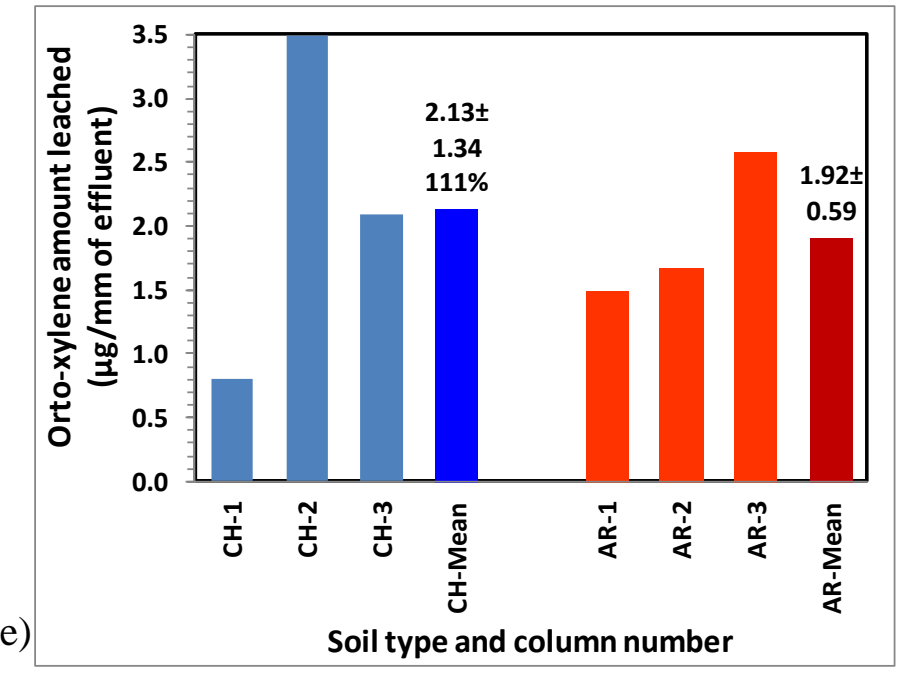

Figure 2. Amount of the aromatic hydrocarbons: benzene (a), toluene (b), ethyl-benzene (c), meta- and para-xylene (d) and orto-xylene (e) leached per mm of effluent beyond the 1-m soil depth from each lysimeter, for AR-eu and $\mathrm{CH}$-ha soil types; the figures in the graphs show the means \pm standard deviations (SD) corresponding to the treatments (soil types); the percentage values of $\mathrm{CH}$-ha-means are expressed versus the AR-eu mean values

The highest amount leached per mm is also reported for benzene, with $51.7 \mu \mathrm{g} / \mathrm{mm}$ (AR-eu) and 43.0 $\mu \mathrm{g} / \mathrm{mm}$ (CH-ha), the last value representing $83 \%$ from the first one. Toluene values $(\mu \mathrm{g} / \mathrm{mm})$, followed in magnitude with 16.2 and 11.3, respectively, and the value corresponding to $\mathrm{CH}$-ha represents $70 \%$ of the value corresponding to AR-eu. The other BTEX hydrocarbons were less mobile and presented much lower values. The values reported for $\mathrm{CH}$-ha were higher compared to those reported for AR-eu.

\subsubsection{Correlation between the amount of the studied BTEX leached and the cumulative effluent volume}

The amount of benzene and toluene leached below $1 \mathrm{~m}$ soil depth is highly significantly and positively correlated with the cumulative effluent volume (Figure $3 \mathrm{a}$ and $3 \mathrm{~b}$ ), for both soil tipes: AR-eu and $\mathrm{CH}-\mathrm{ha}$. As mentioned above, no leachate was noted for the swell-shrink PH-ch-lv. The regression line corresponds to a $2^{\text {nd }}$ degree polynomial function describing an initial sharply increase and then a diminishing trend toward the end of experiment.

The other studied aromatic hydrocarbons present similar correlations, and they are described in Table 1. All relationships are highly significant, and the regression lines correspond to a $2^{\text {nd }}$ degree polynomial 
function. Under continuous water application at the soil surface and involving a permanent downward soil water flux, all these relationships can also be regarded as "leaching attenuation equations" for the BTEX components lost from the $1 \mathrm{~m}$ soil depth, if subtracted from the initial aromatic hydrocarbons' amount spilled over the soil surface area at the beginning of experiment. In other words, these aromatic hydrocarbons incorporated in the first horizons decrease with the water amount applied and effluent volume.

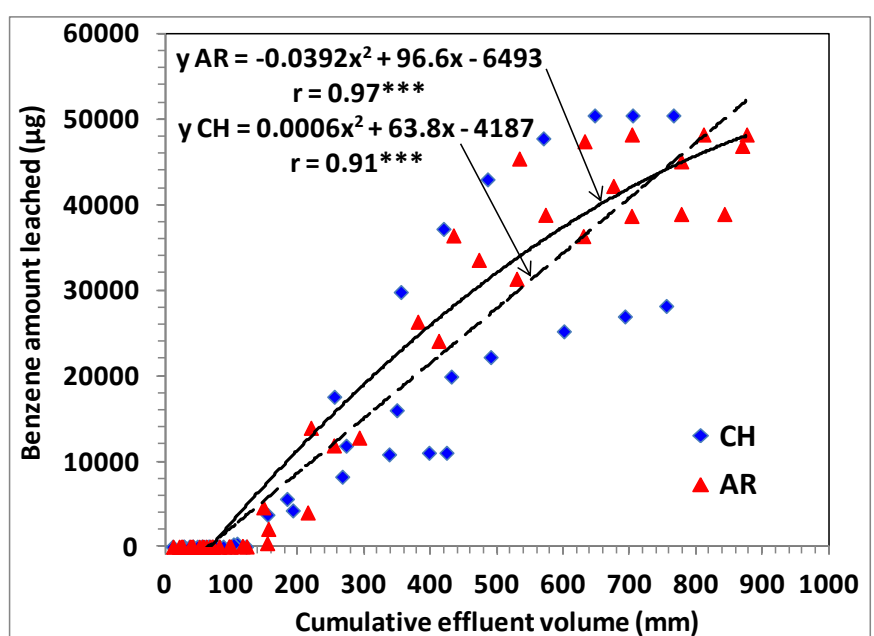

a)

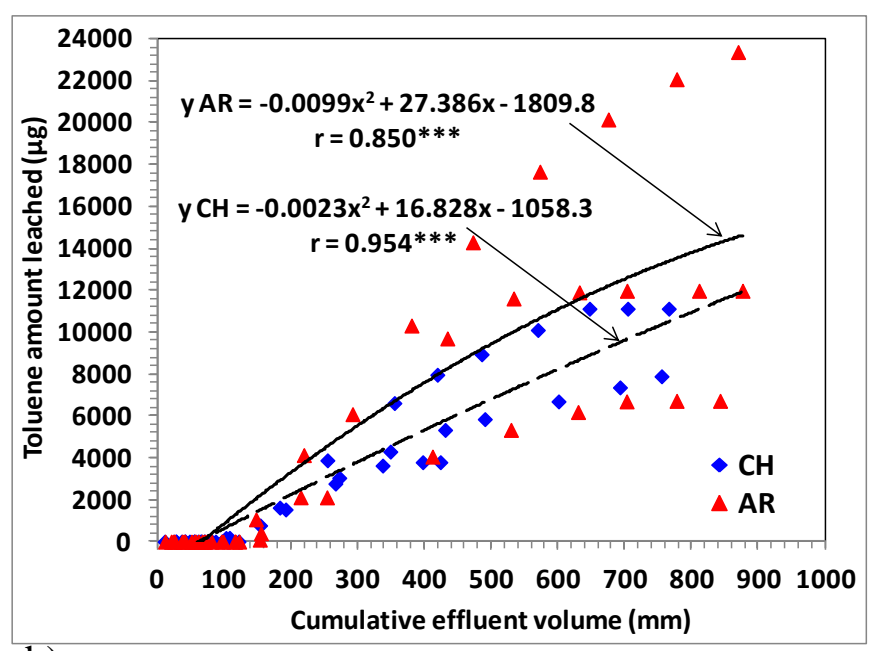

b)

Figure 3. Correlation between the benzene (a) and toluene (b) amounts leached from the main soil root zone of $1 \mathrm{~m}$ depth and the cumulative effluent volume for both $\mathrm{CH}$-ha and AR-eu soil types i; $* * *$ - highly significant $(\mathrm{p} \leq 0.001)$

Table 1. Regression lines and correlation coefficients (r) between the cumulative effluent volume $(\mathrm{x}, \mathrm{mm})$ and the amounts of ethyl-benzene, meta-xylene and para-xylene combined, and ortho-xylene $(\mathrm{y}, \mu \mathrm{g})$ leached from the main soil root zone of $1 \mathrm{~m}$ depth under continuous water application for both $\mathrm{CH}$-ha and AR-eu soil types

\begin{tabular}{|c|c|c|c|c|}
\hline $\begin{array}{c}\text { Hydrocarbons } \\
\text { leached }\end{array}$ & Soil type & Regression line & $\begin{array}{c}\text { Correlation } \\
\text { coefficient }(\mathbf{r})\end{array}$ & Significance \\
\hline \multirow{2}{*}{ Ethylbenzene } & AR-eu & $\mathrm{y}=-0.0004 \mathrm{x}^{2}+1.2220 \mathrm{x}-77.019$ & 0.555 & $\mathrm{p} \leq 0.001$ \\
\cline { 2 - 5 } & CH-ha & $\mathrm{y}=-0.0004 \mathrm{x}^{2}+0.7388 \mathrm{x}-43.592$ & 0.969 & $\mathrm{p} \leq 0.001$ \\
\hline \multirow{2}{*}{$\begin{array}{c}\text { Meta-xylene, } \\
\text { para-xylene }\end{array}$} & AR-eu & $\mathrm{y}=-0.0002 \mathrm{x}^{2}+0.8040 \mathrm{x}-48.102$ & 0.580 & $\mathrm{p} \leq 0.001$ \\
\cline { 2 - 5 } Ortho-xylene & CH-ha & $\mathrm{y}=0.0002 \mathrm{x}^{2}+2.8910 \mathrm{x}-186.37$ & 0.889 & $\mathrm{p} \leq 0.001$ \\
\cline { 2 - 5 } & AR-eu & $\mathrm{y}=-0.0021 \mathrm{x}^{2}+4.0474 \mathrm{x}-261.76$ & 0.944 & $\mathrm{p} \leq 0.001$ \\
\hline
\end{tabular}

However, the BTEX amounts not leached but stored in the soil are estimated to be still considerable if we ignore their volatilization, chemical and biological transformation that were not quantified here. Thus, according to literature $[5,7]$ and assuming that the applied crude oil had the BTEX-components percentage within the values reported by literature [5, 7], an estimation of the leached BTEX components using the data from Figure 3 and Table 1 would be as follows: 50-52 mg of benzene out of 2160 to 2700 mg applied, $24 \mathrm{mg}$ of toluene out of 5520 to $7130 \mathrm{mg}, 2 \mathrm{mg}$ of ethylbenzene out of 2120 to $3680 \mathrm{mg}$, $2.5 \mathrm{mg}$ of $\mathrm{m}$ - and p-xylene out of 5520 to $8280 \mathrm{mg}$, and $3 \mathrm{mg}$ of o-xylene out of 1840 to $8280 \mathrm{mg}$, with a total of $85.3 \mathrm{mg}$ of BTEX components out of 19320 to $28000 \mathrm{mg}$ applied initially, were leached out of the soil. The remained aromatic hydrocarbons are continuously subject to both leaching toward groundwater and altering and transforming into other substances by help of microbiota, but this is not the purpose of this work. 


\subsection{Discussion}

The current experiment focused on leaching of some mobile aromatic hydrocarbons represented by benzene, toluene, ethylbenzene, meta-xylene and para-xylene, and ortho-xylene, where a miscible displacement process occurred during a continuous soil water flux for almost four months. The effluent collected at the small-scale lysimeters bottom was analyzed in dynamics to simulate the transportation process of these substances beyond the main rooting system of the crops. Chemical and biochemical transformations were not approached in this work, and the experiment was carried out during the cold season, with no heat supply in the laboratory in order to decrease the risk of chemical transformations due to higher temperatures; hence, the air temperature varied within a narrow interval, between 8 and $12^{\circ} \mathrm{C}$.

The results presented above have shown a higher penetration as miscible displacement and convective movement of the BTEX-aromatic hydrocarbons investigated here in the AR-eu soils versus the $\mathrm{CH}$-ha soils, as a result of a coarser soil texture and higher permeability of the former. However, in most of the cases these differences between AR-eu and $\mathrm{CH}$-ha soils are not significant, because there was a greater spatial variability among the data in terms of permeability, and consequently in effluent concentration values (Figure 1, Figure 3b). The Luvic-Chernic Phaeozem, PH-ch-lv, containing a higher content of soil-shrink clay minerals, and being saturated with water, was impermeable for all these hydrocarbons because there were no cracks or empty-of-water large macropores to enhance penetration as previously reported by [11] for dry field soils.

From the entire initial oil spill and after such a long period of water application, only a small part of BTEX was leached (Figure 3), which would most probably have flown further downwards, beyond the rooting depth in the soil, and then through the geological deposits toward groundwater. The obtained relationships between the amount of hydrocarbons leached and the effluent volume (Figure 3, Table 1) describe the process of hydrocarbons decrease from the soils. The crude oil from the soil is also subject simultaneously to volatilization, chemical transformation and bioremediation, and all these processes occur with higher efficiency in a period of a few months from soil pollution, similar to the period described in the present experiment [21]. Consequently, during the leaching experiment, a part of the initially applied BTEX components may also have been lost by other transformations. Nevertheless, there still is a potential risk of leaching in the sandy (AR-eu) or loamy soils (CH-ha) due to the stored hydrocarbons in the soils, combined, as mentioned, with a probable chemical transformation and degradation by aerobic and anaerobic bacteria under further warmer climatic conditions following the cold autumn-winter season.

Benzene, one of the most soluble hydrocarbons, and toluene, mostly insoluble yet mobile in a convective movement, were found to be the most leached aromatic hydrocarbons from the studied soils, and are thus the most probably met in groundwater. These finding are consistent with results reported by other scientists [5, 8]. However, unlike some reports [8] where the BTEX components are characterized as all having similar environmental behavior, we found both toluene and the rest of the aromatic hydrocarbons studied, except benzene, as much less leachable.

United States Environmental Protection Agency established the limit of benzene as $1 \mu \mathrm{g} / \mathrm{L}$ in drinking water according to [4], and this limit is $5 \mathrm{mg} / \mathrm{L}$ according to [5] and the same permissible limit was established by Romanian laws as well [41], while World Health Organization recommended less a severe limit, $10 \mu \mathrm{g} / \mathrm{L}$ [6]. With regard to toluene, the maximum admissible value for this crude oil component in drinking water is $1 \mathrm{mg} / \mathrm{L}$ in some states of the USA [5].

Our findings suggest that around the wells where such oil spills occur, as either point- or non-point source, and assuming that the leached benzene or toluene reached groundwater, there is a real risk for human health if the people consume such polluted water. In this context, important amounts of benzene leakage from petrol bunk and stations in groundwater around the Madurai District in India were found [2], and serious risks of cancer specifically among children there were reported. From these two highly leachable hydrocarbons, toluene is the most biodegradable, followed by xylenes, benzene, and ethylbenzene [8]. Not only benzene and toluene, but also the other aromatic hydrocarbons found to be 
leached in this experiment, even in lower amounts, if quickly or slowly reach the groundwater, represent sources of pollution with severe risks for human health.

Another step is to find out how deep and how much these BTEX compounds penetrated into the soil depending on soil physical properties, and this investigation is intended to be carried out in the future.

\section{Conclusions}

The breakthrough curves of the BTEX compounds: benzene, toluene, ethyl-benzene, meta-xylene and para-xylene combined, and ortho-xylene aromatic hydrocarbons show that the highest mobility in the investigated sandy AR-eu soils and loamy $\mathrm{CH}$-ha soils was found for benzene followed by toluene. The other hydrocarbons only showed a limited mobility. There was no leachate from the swell-shrink PH-ch-lv soil type that showed to be impermeable, and such heavy-clay soils are spread over an important part of the oil-well and pipe lands in Romania; soil texture and permeability thus play an important role in the movement of BTEX compounds toward the groundwater.

The breakthrough curves generally showed an asymmetrical shape, and after applying an amount of water of about $200 \%$ from the total soil porosity over the soils, or an equivalent of about $800-850 \mathrm{~mm}$ of precipitation, the leaching process did not end and there still was an important leaching potential remained for these hydrocarbons.

The highest amount leached per mm of effluent was also for benzene followed by toluene, within the sandy AR-eu soils, yet not-significantly higher than in loamy $\mathrm{CH}$-ha soils due to a greater spatial variability within the latter.

There were highly significant, positive correlations between the amounts of the studied hydrocarbons leached and the cumulative effluent volume under a continuous water supply at the soil surface. Such relationships can also be regarded as leaching attenuation curves of the studied aromatic hydrocarbons lost out of the soils. The swell-shrink soils, despite a generally lower fertility, are still an effective barrier to hydrocarbons` movement toward groundwater.

Benzene and toluene, and also the other aromatic hydrocarbons leached from the soils, even in lower amounts, if reach the groundwater represent sources of pollution with severe risks for human health.

The depth and amount of the BTEX compounds penetrated as a function of the soil physical properties, not leached but stored for a longer period in the soil, represent future goals to be carried out.

\section{References}

1. IFELEBUEGU, A.O., UKPEBOR, J.E., AHUKANNAH. A.U., NNADI, E.O., THEOPHILUS, S.C., Environmental effects of crude oil spill on the physicochemical and hydrobiological characteristics of the Nun River, Niger Delta. Environ. Monit. Assess. 189(4): 2017, 173, doi: 10.1007/s10661-017-5882x. Epub 2017 Mar 20.

2.SENTHIL KUMAR, M., SIVASANKAR, V., GOPALAKRISHNA, G.V.T., Quantification of benzene in groundwater sources and risk analysis in a popular South Indian Pilgrimage City - A GIS based approach. Arab. J. Chem., 10(2): 2017, S2523-S2533, doi.org/10.1016/j.arabjc.2013.09.022.

3. RIYADH, AL-R., NGUELEU, S., REZANEZHAD, F., VAN CAPPELLEN, PH., Groundwater pollution by petroleum-derived contaminants in coastal semiarid environment. Energy Envron-Poster Display, 2018, doi.org/10.5339/qfarc.2018.EEPD709.

4. ***USEPA, Guidelines For Carcinogen Risk Assessment, EPA/630/P-03?001F, US EPA, Agency Risk Assessment Forum, Washington D.C., 2005.

5. WILLIAMS, S.D., LADD, D.E., FARMER, J.J., Fate and transport of petroleum hydrocarbons in soil and ground water at big South Fork National River and Recreation Area, Tennessee and Kentucky, 20022003. Sci. Invest. Rep. 2005-5104. U.S. Geological Survey, Reston, Virginia, 2006.

6. ***WHO, Guidelines for drinking-water quality. $3^{\text {rd }}$ edition incorporating 1 st and 2 nd addenda. Vol. 1. Recommend., Geneva, 2008, 312-313.

7.YANG, C., BROWN, C.E., HOLLEBONE, B., YANG, Z., LAMBERT, P., FIELDHOUSE, B., LANDRIAULT, M., WANG, Z., Chapter 4 - Chemical Fingerprints of Crude Oils and Petroleum 
Products. In: Oil Spill Science and Technology (Second Edition): Environ. Clim. Chang. Canada, 2017, 209-304, doi.org/10.1016/B978-0-12-809413-6.00004-7.

8. POPEK, E. Sampling and analysis of environmental chemical pollutants (Second Edition). Chapter 2 - Environ. Chem. Pollut., 2018, 13-69. doi.org/10.1016/B978-0-12-803202-2.00002-1.

9. BIGGAR, J.W., NIELSEN, D.R., Miscible Displacement and Leaching Phenomenon. Irrigation of Agricultural Lands: In: Hagan R.M., Haise H.R., Edminster T.W. (Eds.): Agron. Monogr., Chapter 14, 1967, 254-274, doi.org/10.2134/agronmonogr11.c15.

10. CATT, J., The Brimstone Experiment - Collaborative Work by ADAS' Field Drainage Experimental Unit and Rothamsted Experimental Station - Conference Proceedings (Paperback). Book, 1991, ISBN 978-0-9514456-3-1.

11. PALTINEANU, C., Nutrient leaching in a cracked vertisol in Romania. Agron. 21(5), 2001, 427433, doi.org/10.1051/agro:2001135.

12. LĂCĂTUȘU, R., PALTINEANU, C., VRINCEANU, A., LĂCĂTUȘU, A.R., Influence of domestic activity on the quality of groundwater and surface water in the rural built-up area of the southern Romanian Danube Plain - a case study in the Glavacioc catchment. Carpath. J. Earth. Env. Sci., 14(2), 2019, 323-334, DOI:10.26471/cjees/2019/014/083.

13. ZHAO, M., CHEN, X., SHI, Y., ZHOU, Q., LU, C., Phosphorus Vertical Migration in Aquic Brown Soil and Light Chernozem Under Different Phosphorous Application Rate: A Soil Column Leaching Experiment, Bull. Environ. Contam. Toxicol., 82, 2009, 85-89, DOI 10.1007/s00128-008-9586-3.

14. CHAOZI, W., MCNEW, C.P., LYON, S.W., WALTER, M.T., VOLKMAN, T.H.M., ABRAMSON, N., SENGUPTA, A., WANG, Y., MEIRA NETO, A.A., PANGLE, L., TROCH, P.A., KIM, M., HARMAN, C., DAHLKE, H.E., Particle tracer transport in a sloping soil lysimeter under periodic, steady state conditions, J. Hydrol., 569, 2019, 61-76.

15. DOMNARIU, H., PALTINEANU, C., MARICA, D., LĂCĂTUȘU, A.R., RIZEA, N., LAZĂR, R., POPA, G.A., VRINCEANU, A., BĂLĂCEANU, C., Influence of soil-texture on nitrate leaching from small-scale lysimeters toward groundwater in various environments. Carpath. J. Earth. Env. Sci., 15(2), 2020, 301-310; Doi:10.26471/cjees/2020/015/130.

16. KOSTECKI, P., MORRISON, R., DRAGUN, J., Hydrocarbons. In: Hillel D. (Editor-in-Chief) Encyclopedia of Soils in the Environment, 2005, 217-226, doi.org/10.1016/B0-12-348530-4/00098-9.

17. TOTI, M., DUMITRU, M., CĂPITANU, V., DRACEA, M., CONSTANTIN, C., CRĂCIUN, C., Poluarea cu petrol şi apă sărată a solurilor din România, RISOPRINT, Cluj-Napoca, 1999, 254 pp.

18. MARINESCU, M., TOTI, M., TANASE, V., CARABULEA, V., PLOPEANU, G., CALCIU, I., An assessment of the effects of crude oil pollution on soil properties. Anns. Food Sci. Technol., 11(1), 2010, 94-99.

19. LĂCĂTUŞU, A.R., COCÂRŢĂ, D., LĂCĂTUŞU, R., Ex-situ bioremediation efficiency in removing organic and inorganic compounds from artificially and anthropogenic contaminated soils, Carpath. J. Earth. Env. Sci., 8(1), 2013, 59- 70.

20. LĂCĂTUȘU, A.R, LĂCĂTUȘU. R., DUMITRU. M., MORARU. I-R, VRÎNCEANU. A., BĂLĂCEANU. C., BURTAN. L., Decontamination of a petroleum hydrocarbons polluted soil by different bioremediation strategies. Ann. Univ. Craiova, Agriculture, Montanology, Cadastre Series, XLVI, 2016, 326-334.

21.COCÂRŢĂ. D.M., DUMITRU. D.M., LĂCĂTUȘU. A.R., BADEA. A., Evaluation of bioremediation efficiency in crude-oil contaminated soils (Conference Paper). International Multidisciplinary Scientific GeoConference Surveying Geology and Mining Ecology Management, SGEM, 4(BOOK 1), 2016, 103-110, 16th International Multidisciplinary Scientific GeoConference, SGEM 2016; HOFBURG Congress CentreVienna; Austria; 2 November 2016 through 5 November 2016; Code 124226.

22. PALTINEANU, C., MIHAILESCU, I.F., TORICA, V., ALBU, A.N., Correlation between sunshine duration and global solar radiation in south-eastern Romania. Int. Agrophys. 16(2), 2002, 139-145. 
23. PALTINEANU, C., MiHAILESCU, I.F., SECELEANU, I., DRAGOTA, C., VASENCIUC, F., Ariditatea, seceta, evapotranspiraţia şi cerinţele de apă ale culturilor agricole în România. Editura Ovidius University Press, Constanţa, 2007, 319 pp.

24. PALTINEANU, C., CHITU, E, MATEESCU, E., Changes in crop evapotranspiration and irrigation water requirements, Int. Agrophys., 25(4), 2011a, 369-373.

25. PALTINEANU, C., CHITU, E., MATEESCU, E., New trends for reference evapotranspiration and climatic water deficit, Int. Agrophys., 26(2), 2012, 159-165.

26. PALTINEANU, C., CHITU, E, TANASESCU, N. Irrigation water requirements for some fruit trees specific to the Arges-Vedea river basin, Romania. Acta Hort., 537, 2000, 113-119.

27. PALTINEANU, C., CHITU, E., TANASESCU, N., Correlation between the Crop Water Stress Index and Soil Moisture Content for Apple in a Loamy Soil: a Case Study in Southern Romania. Acta Hort. 889, 2011, 257-264.

28. JONES, A., MONTANARELlA, L., MICHELI, E., SPAARGAREN, O., JONES, R.J.A., Major soil types of Europe. EC JRC, EU Publication Office, Luxembourg, 2010.

29. FLOREA, N., MUNTEANU, I., Romanian Soil Taxonomy system-SRTS. Sitech, Craiova, 2012, $206 \mathrm{pp}$.

30. ***World reference base for soil resources 2014. International soil classification system for naming soils and creating legends for soil maps. Update. FAO of the UN, Rome, Italy, 2015, 193.

31. FLOREA, N., BĂLĂCEANU, V., RĂUȚĂ, C., CANARACHE, A., Metodologie de elaborare a studiilor pedologice, Partea I, II și III, Redacția de Propagandă Tehnică Agricolă, ICPA București, 1987. 33. HILLEL, D., Applications of soil physics. Academic Press. New York. USA, 1980.

32. PALTINEANU, C., NICOLAE, S., TANASESCU, N., CHITU, E., ANCU, S., Investigating Root Density of Plum and Apple Trees Grafted on Low-Vigor Rootstocks to Improve Orchard Management, Erwerbs-Obstbau, 59, 2016a, 29-37, DOI 10.1007/s10341-016-0293-7.

34. CANARACHE, A., Fizica solurilor agricole, Editura Ceres, 1990.

35. PALTINEANU, C., TANASESCU, N., CHITU, E., Pattern of soil physical properties in intensive plum and apple orchards on medium and course textured soils. Soil Till. Res. 163(C), 2016b, 80-88, DOI: 10.1016/j.still.2016.05.013.

36. PALTINEANU, C., VRINCEANU, A., LĂCĂTUȘU, A.R., LĂCĂTUŞU, R., DOMNARIU, H., MARICA, D., VIZITIU, O., An improved method to study solute leaching in large undisturbed soil columns near field capacity toward the groundwater in various environments. Carpath. J. Earth. Env. Sci., 15(1), 2020, 93-102, DOI:10.26471/cjees/2020/015/112.

37. MARINESCU, M., MANEA, A., LACATUSU, A., GAMENT, E., PLOPEANU, G., Correlation between the dynamics of petroleum hydrocarbons concentration and bioremediation process efficiency in soil polluted with crude oil. International Multidisciplinary Scientific GeoConference Surveying Geology and Mining Ecology Management, SGEM, 17(32), 2017, 117-124.

38 .***U.S. Department of Energy, Strategic petroleum reserve crude oil assay manual (2d ed.): Washington D.C., U.S. Department of Energy, 2002, 30 pp.

39. RAUCKYTE, T., ŻAK, S., PAWLAK, Z., OLOYEDE, A. 2010. Determination of oil and grease, total petroleum hydrocarbons and volatile aromatic compounds in soil and sediment samples. J. Environ. Eng. Landsc. Manag. 18(3), doi.org/10.3846/jeelm.2010.19.

40. BELLAR, T., Measurement of volatile organic compounds in soils using modified purge-andtrap and capillary gas chromatography/mass spectrometry, U.S. Environmental Protection Agency, Environmental Monitoring Systems Laboratory, Cincinnati, OH, November, 1991.

41.***Legea 458/2002 privind calitatea apei potabile. Monitorul oficial al României, Partea I, nr. 875/12.XII.2011.

Manuscript received: 16.05 .2020 